\title{
Nitrogen and Light Affect Water Use and Water Use Efficiency of Zoysiagrass Genotypes Differing in Canopy Structure
}

\author{
John E. Erickson ${ }^{1}$ and Kevin E. Kenworthy \\ Agronomy Department, University of Florida, P.O. Box 110965, Gainesville, \\ FL 32611
}

Additional index words. water conservation, nitrogen fertilization, water relations, gas exchange, turfgrass physiology

\begin{abstract}
Irrigation of residential lawns represents one of the major uses of potable water in many regions. An increased understanding of physiological responses underlying effects of turfgrass genotypes and management practices on water use rates and water use efficiencies could contribute to water conservation. Thus, we evaluated the effects of nitrogen $(\mathrm{N})$ fertilization $\left(0.0\right.$ and $2.5 \mathrm{~g} \cdot \mathrm{m}^{-2}$ ) and light environment (full sun and $50 \%$ shade) on average daily evapotranspiration $\left(\mathbf{E T}_{\mathrm{AVE}}\right)$, daily ET per unit leaf area $\left(\mathbf{E T}_{\mathbf{L A}}\right)$, carbon exchange rate (CER), and water use efficiency (WUE) in upright (experimental TAES 5343-22) and prostrate ('Empire') zoysiagrasses (Zoysia japonica Steud.) during two repeated trials. Across all treatments, ET $_{\mathrm{AVE}}$ was 4.0 and $5.4 \mathrm{~mm} \cdot \mathrm{d}^{-1} \mathrm{during}$ Trials 1 and 2 , respectively. In the upright-growing genotype, $\mathbf{E T}_{\mathrm{AVE}}$ was $\approx 10 \%$ greater than the prostrate genotype during Trial 1 . Nitrogen fertilization increased water use by $\approx \mathbf{2 0} \%$ compared with non-fertilized pots. However, $\mathrm{N}$ fertilization reduced $\mathrm{ET}_{\mathrm{LA}}$ and increased WUE. Thus, ET $_{\mathrm{AVE}}$ was positively related with WUE. As a result, there was a tradeoff between ET $_{\mathrm{AVE}}$ and WUE, indicating that efforts to achieve reductions in water use through low $\mathrm{N}$ fertilization or genotypes can be accomplished, but in some cases at the expense of using water less efficiently to assimilate carbon for plant growth processes. In turfgrass, reductions in growth and WUE might be acceptable to minimize water use, but vigor and quality need to be maintained.
\end{abstract}

Water and nutrient inputs are frequently applied to residential and commercial turfgrass landscapes to maintain growth and quality. The application of water to residential landscapes represents one of the major uses of potable water in many areas. For example, it was estimated that approximately two-thirds of average household water consumption in Central Florida was used for landscape irrigation (Haley et al., 2007). Thus, in many regions, this has led to water restrictions, especially during drought, that limit residential irrigation in an effort to conserve water. In addition, irrigation can contribute to leaching losses of applied N (Morton et al., 1988), which poses a significant environmental threat (Carpenter et al., 1998). Consequently, much attention has been focused on developing turfgrass germplasm and management practices that contribute to reduced water use and increased efficiency of water use by turfgrass systems. However, in many cases, we still lack a basic understanding of the physiological responses underlying effects of turfgrass genotypes and management practices on water use rates and particularly efficiencies of water use by turfgrass.

\footnotetext{
Received for publication 22 Dec. 2010. Accepted for publication $24 \mathrm{Jan} .2011$.

${ }^{1}$ To whom reprint requests should be addressed; e-mail jerickson@ufl.edu.
}

A number of factors have been shown to affect turfgrass ET rates. Lower mowing heights have been shown to reduce ET (Feldhake et al., 1983; Fry and Butler, 1989). In addition, increased fertilization generally results in increased ET from turfgrass (Barton et al., 2009; Ebdon et al., 1999; Feldhake et al., 1983). Decreased solar radiation and/or shade result in lower ET rates (Feldhake et al., 1983). Finally, species selection has been shown to influence ET, and in particular cool-season grasses generally have higher ET rates than warm-season grasses (Biran et al., 1981; Feldhake et al., 1983; Qian and Engelke, 1999). In addition to species differences, substantial variation among cultivars within a species has also been reported. (Ebdon and Petrovic, 1998; Shearman, 1989). Relatively lower ET rates have been associated with several plant traits, including horizontal leaf orientation, narrow leaf texture, high shoot density, and low leaf area (Ebdon and Petrovic, 1998; Kim and Beard, 1988). In fact, the factor that varied the most among high- and lowwater use cultivars of kentucky bluegrass was horizontal leaf orientation, because low-water use cultivars had $17 \%$ more horizontal leaf orientation (Ebdon and Petrovic, 1998).

In addition to absolute water use by turfgrass (i.e., ET), the efficiency with which that water is used to produce turf biomass may also contribute to improved water conservation. Water use efficiency is a measure of carbon assimilated per unit of water transpired by the plant (Stanhill, 1986) and can be measured instantaneously using gas exchange approaches (e.g., Bunce, 2010) or integrated over time using cumulative biomass and transpiration measures or tissue carbon isotope composition (e.g., Ebdon et al., 1999). Although each of these methods has advantages and disadvantages, they all generally agree very well (Condon et al., 2004; Ebdon et al., 1999; Heitholt, 1989). Although there are numerous data on individual factors affecting turfgrass water use, our basic understanding of how these factors interact to affect water use and especially WUE is still limited. Ebdon et al. (1999) reported that ET was negatively related to WUE in kentucky bluegrass at low temperatures (i.e., low ET) indicating that water conservation and high WUE could be simultaneously achieved, but they did not find the same relationship at higher temperatures. Higher WUE has been reported for slow-release $\mathrm{N}$ fertilizers (Saha et al., 2005). Other studies have shown that $\mathrm{N}$ fertilization is positively related to WUE (Brueck, 2008; Heitholt, 1989), but it is not clear what the implications for growth/quality, ET, and water conservation might be with higher WUE associated with $\mathrm{N}$ fertilization (Barton et al., 2009; Blum, 2009).

It is becoming increasingly apparent that no single crop trait or cultural practice will be adequate for achieving water conservation in turfgrass systems. We must improve our understanding of the complexity of interactions and physiological responses to achieve water conservation across a wide range of environments. Therefore, the objectives of the current study were to evaluate the effects of $\mathrm{N}$ fertilization and light environment on relations among growth, carbon assimilation, water use, and WUE of two coarse-textured Zoysia japonica Steud. genotypes differing in canopy architecture. Zoysiagrasses provide a high-quality turf, have good shade tolerance, and are adapted to a variety of soils, but widespread adoption has been limited in part as a result of relatively high water use rates and poor drought resistance (Carrow, 1995; Qian and Engelke, 1999). Thus, we specifically wanted to test whether $\mathrm{N}$ fertilization would affect daily ET, daily ET per unit leaf area, carbon exchange rate, biomass, and WUE and whether these relations would differ by genotype and/or light environment.

\section{Materials and Methods}

Experimental site and design. A repeated outdoor pot study was conducted at the University of Florida in Gainesville, FL (long. $29^{\circ} 63^{\prime} \mathrm{N}$, lat. $82^{\circ} 35^{\prime} \mathrm{W}$ ). Trial 1 was conducted from 1 through 7 July 2009 and Trial 2 was conducted from 15 through 29 May 2010. Trials were limited to less than 3 weeks as a result of the intensive nature of the data collection and to avoid clipping the grasses and changing seasonal/environmental conditions on ET. Pots were filled with a commercially available medium-fine sand (No. 1113; Quikrete International Inc., Atlanta, GA) mixed 
with a sphagnum peatmoss (Conrad Fafard Inc., Agawam, MA) at 9 parts sand:1 part peat by volume. The root-zone substrate was well mixed and added to each of $60-\mathrm{cm}$ long polyvinyl chloride pots. Large-diameter pots (15.2 $\mathrm{cm}$; approximately four times canopy height) were chosen to minimize border effects on canopy interactions with environment. Plugs (10.2 cm diameter) of two coarsetextured zoysiagrass genotypes were collected from field plots near Gainesville, FL. 'Empire' zoysiagrass was selected for its prostrate leaf growth habit (mean leaf angle of $21^{\circ}$ and mean leaf width of $12 \mathrm{~mm}$ ), whereas experimental TAES 5343-22 from the UF Turf Breeding Program in collaboration with Texas Agrilife Research was selected for its upright leaf growth habit (mean leaf angle of $40^{\circ}$ and mean leaf width of 10 $\mathrm{mm})$. The field plugs were transplanted into the experimental pots and were allowed to establish for 3 months before the experiment began. Half of the pots became established under full natural sunlight, whereas half were under $\approx 50 \%$ full sunlight (Fig. 1). The turf canopy of the shade pots was $\approx 30 \mathrm{~cm}$ below a knit high-density polyethylene $50 \%$ white shadecloth (Gempler's, Madison, WI). All pots were fertilized $7 \mathrm{~d}$ after planting and 7 weeks after planting with $2.5 \mathrm{~g} \mathrm{~N}$ (as ammonium phosphate, potassium nitrate, and urea)/ $\mathrm{m}^{2}$ of a liquid fertilizer $(15 \mathrm{~N}-2.2 \mathrm{P}-12.5 \mathrm{~K})$ with micronutrients (Miracle-Gro Excel, Marysville, $\mathrm{OH})$. At 12 weeks after planting, the $\mathrm{N}$ fertilization treatment was imposed with half the pots receiving fertilization again

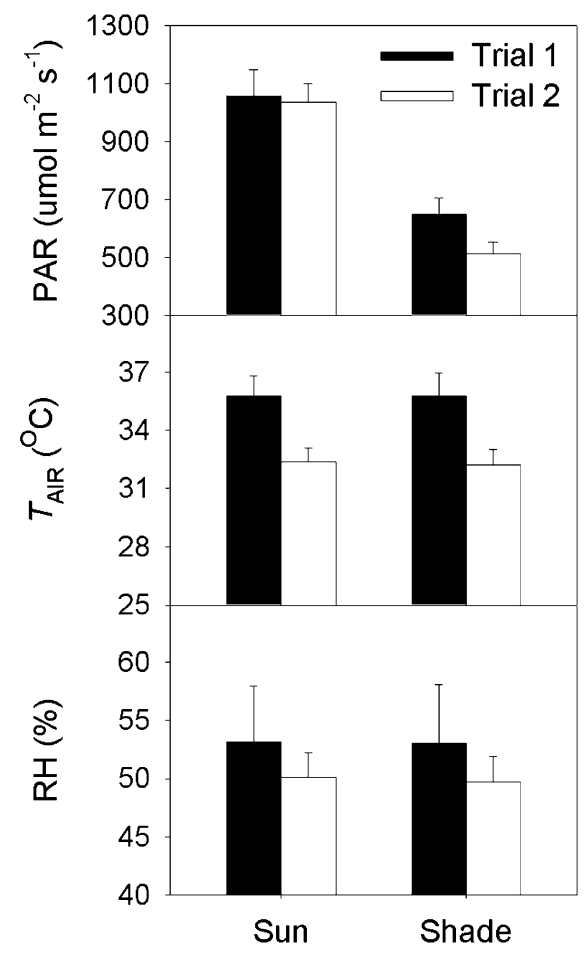

Fig. 1. Average daily relative humidity $(\mathrm{RH})$, air temperature $\left(T_{\mathrm{AIR}}\right)$, and photosynthetically active radiation $(P A R)$ for the sun and shade treatments during Trials 1 and 2 of the study. Error bars represent SE of the mean.
(2.5 g N/m $\mathrm{m}^{2}$ treatment) and half receiving no further fertilization $\left(0.0 \mathrm{~g} \mathrm{~N} / \mathrm{m}^{2}\right.$ treatment $)$. Thus, the experiment was a multifactorial experiment that consisted of 48 pots arranged in a completely randomized design. Genotype, $\mathrm{N}$ fertilization, and light environment were the three factors included in the experiment. During establishment, all pots were maintained at a height of $4 \mathrm{~cm}$ and were trimmed to a height of $4 \mathrm{~cm}$ at onset of data collection.

Climate and water use. Air temperature $\left(T_{\mathrm{AIR}}\right)$ and relative humidity $(\mathrm{RH})$ were measured at turfgrass canopy height in the sun and shade treatments every minute and stored as 15 -min averages using $\mathrm{HOBO}^{\circledR}$ Pro v2 data loggers (Onset Computer Corp., Bourne, MA). Photosynthetically active radiation $(P A R)$ was measured at canopy height in the sun and shade treatments using LI-190 quantum sensors (LICOR Inc., Lincoln, NE). The PAR data were measured every $15 \mathrm{~s}$ and stored as $15-\mathrm{min}$ averages to a data logger throughout each experiment.

Evapotranspiration was measured using the water balance method by weighing the pots at $\approx 0700 \mathrm{HR}$ each morning and $2100 \mathrm{HR}$ each evening. Data on water use were not collected on days when rainfall was received. Pots were filled to field capacity at the onset of the experiment and refilled every $2 \mathrm{~d}$ to replace ET to maintain non-limiting soil moisture.

Carbon exchange rate, growth, and water use efficiency. Canopy carbon and water exchange were measured using a LI-COR 6400 XT Infrared gas analyzer (LI-COR Inc.) with a modified chamber (LI-COR, 2009). The chamber (13 cm length and $15.2 \mathrm{~cm}$ o.d.) was constructed from clear cast acrylic tube (U.S. Plastic Corp., Lima, OH). Weatherstripping on the bottom of the chamber served as a gasket and sealed tightly on the polyvinyl chloride pots to measure canopy carbon and water exchange rates under ambient radiation and temperatures. Net carbon exchange data were measured as $\mu \mathrm{mol} \mathrm{CO}_{2} / \mathrm{m}^{2}$ ground area/ s and water as $\mathrm{mmol} \mathrm{H}_{2} \mathrm{O} / \mathrm{m}^{2}$ ground area/s. Instantaneous WUE $\left(\mu \mathrm{mol} \mathrm{CO} / \mathrm{CO}_{2} / \mathrm{mmol} \mathrm{H}_{2} \mathrm{O}\right)$ was calculated as the ratio of net carbon uptake to water evapotranspired. Gas exchange data were collected on two occasions during the study during the middle of the day under clear sky conditions.

At the end of each experiment, all aboveground tiller biomass was clipped at the soil surface, and all thatch was removed. A representative subsample of 10 tillers from each pot was selected and leaf angles relative to the shoot were measured to the nearest degree using a digital torpedo level (Craftsman Model 320.48295; Sears Roebuck and Co., Hoffman Estates, IL). Subsequently, all leaf blades from the subsample were removed at the collar and scanned as images using a digital scanner. The images were used to determine leaf area using ASSESS Version 2.0 image analysis software (American Phytopathological Society, St. Paul, MN). Leaf blades and remaining stems of the subsample and the rest of the shoot samples were all oven-dried at $60{ }^{\circ} \mathrm{C}$ and weighed after $72 \mathrm{~h}$. Specific leaf area
(SLA) was determined from the area of the leaf subsample $\left(\mathrm{cm}^{2}\right)$ divided by the weight $(\mathrm{g})$. Single-sided leaf area index (LAI) was estimated by taking the fraction of leaf to stem zweight $\times$ total aboveground tiller weight $\times$ SLA. Evapotranspiration per unit leaf area $\left(\mathrm{ET}_{\mathrm{LA}}\right)$ was determined from the average daily ET over the LAI for each pot.

Data analysis. Treatment means and significant treatment effects and their interactions were identified by analysis of variance (ANOVA) using the generalized mixedmodel procedure (GLIMMIX) of the SAS system (SAS 9.2, Cary, NC; Littell et al., 2006). Data were analyzed separately by trial as a result of multiple significant treatment interactions between trials. Where appropriate, day was treated as a random effect. Given the complexity of the factors and significant effects, data were presented as light environment $\times$ genotype $\times \mathrm{N}$ rate means with ANOVA results. Although this does make it somewhat difficult to look at significant main effect means, this was one of the most efficient ways of presenting all the data and significant main effect means were presented in text as discussed. Each treatment was replicated six times for growth and water use measurements and a subset of three replicates was used for the gas exchange measurements as a result of time constraints for collecting the data. Degrees of freedom were determined using the Kenwood-Roger method (Littell et al., 2006). Residuals from each model fit were analyzed for homogeneity of variance graphically and for normality both graphically and numerically with the ShapiroWilk W test.

\section{Results}

Climate. During days of data collection for water use, $T_{\mathrm{AIR}}$ and $\mathrm{RH}$ did not differ between the sun and shade treatments (Fig. 1). Daily average (745 HR to $2030 \mathrm{HR}$ ) $T_{\mathrm{AIR}}$ was $35.8{ }^{\circ} \mathrm{C}$ and ranged from 32.8 to $38.5^{\circ} \mathrm{C}$ during Trial 1 (Fig. 1). During Trial 2, $T_{\mathrm{AIR}}$ averaged $32.2{ }^{\circ} \mathrm{C}$ and ranged from 28.0 to $34.1^{\circ} \mathrm{C}$. Mean RH during the day was $60.2 \%$, ranging from $41.7 \%$ to $79.0 \%$ for Trial 1 (Fig. 1). Mean $\mathrm{RH}$ during the day was $50.0 \%$, ranging from 41.9 to $60.2 \%$ for Trial 2 . Average daily photosynthetic photon flux density was 648 and $512 \mu \mathrm{mol} \cdot \mathrm{m}^{-2} \cdot \mathrm{s}^{-1}$ in the shade treatment and was 1056 and 1034 $\mu \mathrm{mol} \cdot \mathrm{m}^{-2} \cdot \mathrm{s}^{-1}$ for the full sun treatment during Trials 1 and 2, respectively (Fig. 1). Thus, $P A R$ received by the shade treatment was generally between $50 \%$ and $60 \%$ of the full sun treatment. Although RH was lower during Trial 2 , daily average $T_{\mathrm{AIR}}$ was also lower, and thus differences in daily evaporative demand were not that different between the two trials. As expected, $P A R$ and $T_{\mathrm{AIR}}$ tended to be positively correlated, whereas RH was negatively correlated with $P A R$ and $T_{\mathrm{AIR}}$, all providing variation in daily evaporative demand.

Water use. During Trial 1, daily water use varied approximately threefold across all treatments and all days ranging from $2.1 \mathrm{~mm}$ per 
pot to $7.1 \mathrm{~mm}$ per pot. Across all treatments, average daily ET (ET $\left.\mathrm{EVE}_{\mathrm{AVE}}\right)$ was 4.0 and 5.4 $\mathrm{mm} \cdot \mathrm{d}^{-1}$ during Trials 1 and 2, respectively. The most pronounced treatment effect on $\mathrm{ET}_{\mathrm{AVE}}$ across both trials resulted from $\mathrm{N}$ fertilization (Fig. 2), because significantly greater $(P<0.001) \mathrm{ET}_{\mathrm{AVE}}$ was seen in the $\mathrm{N}$-fertilized pots (Tables 1 and 2). Average daily ET was $26 \%$ greater in Trial 1 and $17 \%$ greater in Trial 2 for fertilized pots compared with the non-fertilized pots. Although not as great in magnitude, the upright growing zoysiagrass (TAES 5343-22) had a higher $(P<0.001)$ $\mathrm{ET}_{\mathrm{AVE}}, \approx 10 \%$ greater than the prostrate zoysiagrass in Trial 1 (Table 1). However, no effect of genotype on $\mathrm{ET}_{\mathrm{AVE}}$ was found during Trial 2 (Table 2). Sun-grown pots had greater $\mathrm{ET}_{\mathrm{AVE}}(P<0.001)$ compared with shadegrown pots in Trial 2 (Table 2), but not during Trial 1.

Although $\mathrm{N}$ fertilization increased $\mathrm{ET}_{\mathrm{AVE}}$, it significantly decreased average daily ET per unit leaf area $\left(\mathrm{ET}_{\mathrm{LA}}\right)$ by over $20 \%$ in both trials (Tables 1 and 2). Similarly, plants grown in the sun had significantly $(P<0.05)$ lower $\mathrm{ET}_{\mathrm{LA}}$ compared with shade-grown plants in both trials. In addition to significant main effects, a significant interaction was found between light environment and genotype during Trial 2 (Table 2). Turf $\mathrm{ET}_{\mathrm{LA}}$ increased to a greater extent from shade-grown plants to sungrown plants for the upright genotype compared with the prostrate genotype.

Growth, carbon exchange rate, and water use efficiency. Across all treatments, LAI averaged 4.6 and $4.7 \mathrm{~m}^{2} \cdot \mathrm{m}^{-2}$ during Trials 1 and 2 , respectively. Leaf area index was greater with $\mathrm{N}$ fertilization in Trial 1, and both LAI and total aboveground dry weight were greater in Trial 2 (Tables 1 and 2). Nitrogen fertilization increased LAI by $57 \%$ in Trial 1 and 54\% in Trial 2. Specific leaf area was significantly greater with $\mathrm{N}$ fertilization in both trials (Tables 1 and 2). In addition, SLA was greater in shade plants compared with sun plants and varied by genotype in response to $\mathrm{N}$ with the upright growing zoysiagrass differing between high and low $\mathrm{N}$, although the prostrate-growing zoysiagrass showed no difference in SLA between high and low $\mathrm{N}$ treatments. Canopy carbon exchange rates were significantly greater in $\mathrm{N}$-fertilized pots during both trials.

Instantaneous measures of WUE were increased over $20 \%$ with $\mathrm{N}$ fertilization during both trials (Tables 1 and 2). In addition, WUE was greater in the shade compared with full sun. During Trial 2, WUE increased from sun to shade to a greater extent in the prostrate genotype compared with the upright genotype



Fig. 2. Average daily water use $\left(\mathrm{ET}_{\mathrm{AVE}}\right)$ by genotype and nitrogen treatment for sun-grown plants throughout Trial 1 (left) and Trial 2 (right). Error bars represent SE of the mean for each treatment on each day and are smaller than the symbol if not visible.

(Table 2). In Trial 1, the prostrate genotype showed a greater increase with $\mathrm{N}$ compared with the upright genotype (Table 1). We found that WUE was positively related $(P<0.01)$ with absolute daily water use $\left(\mathrm{ET}_{\mathrm{AVE}}\right)$, indicating a tradeoff in reduced water use with efficiency of water use to assimilate carbon (Fig. 3).

\section{Discussion}

The primary objective of the current study was to examine effects of $\mathrm{N}$ fertilization and light environment on water use and WUE under well-watered conditions of two zoysiagrass genotypes differing in canopy leaf angle orientation. The results from this study indicated that genotype selection (i.e., prostrate growth habit) and especially reduced $\mathrm{N}$ fertilization could contribute to reduced water use by turfgrass. However, we saw no interactive effect of light, $\mathrm{N}$, and/or genotype on average daily water use in either trial as a result of associated changes in morphology and growth. Although no added $\mathrm{N}$ was associated with decreased water use, there was a tradeoff in WUE with low $\mathrm{N}$ plants using water less efficiently for net carbon uptake.

Although average daily water use differed by trial, $\mathrm{ET}_{\mathrm{AVE}}$ rates were similar to those reported elsewhere for zoysiagrass. For example, Kim and Beard (1988) reported ET values ranging from 4.7 to $6.5 \mathrm{~mm} \cdot \mathrm{d}^{-1}$ for two zoysiagrass genotypes grown in minilysimeters in the field in Texas. Green et al. (1991) reported an average of $4.1 \mathrm{~mm} \cdot \mathrm{d}^{-1}$ for 11 zoysiagrass genotypes and found no difference among genotypes in the field but reported differences when grown in environmental chambers. Consistent with other studies (Ebdon and Petrovic, 1998; Kim and Beard, 1988), we also found that the upright-growing genotype used relatively more water, especially in the shade, during Trial 1 . However, it is unclear why this effect was not significant during Trial 2. The difference in LAI between the genotypes

Table 1. Trial 1 treatment means and analysis of variance results for daily average evapotranspiration $\left(\mathrm{ET}_{\mathrm{AVE}}\right)$, daily average $\mathrm{ET}$ per unit leaf area $\left(\mathrm{ET}_{\mathrm{LA}}\right)$, total aboveground dry weight (DW), leaf area index (LAI), specific leaf area (SLA), light saturated canopy carbon exchange rate (CER), and water use efficiency (WUE). ${ }^{\mathrm{z}}$

\begin{tabular}{|c|c|c|c|c|c|c|c|c|c|}
\hline Light & Genotype & Nitrogen & $\begin{array}{c}\mathrm{ET}_{\mathrm{AVE}} \\
\left(\mathrm{mm} \cdot \mathrm{d}^{-1}\right)\end{array}$ & $\begin{array}{c}\text { LAI } \\
\left(\mathrm{m}^{2} \cdot \mathrm{m}^{-2}\right)\end{array}$ & $\begin{array}{c}\mathrm{ET}_{\mathrm{LA}} \\
\left(\mathrm{mm} \cdot \mathrm{d}^{-1} \cdot \mathrm{m}^{-2}\right)\end{array}$ & $\begin{array}{c}\mathrm{DW} \\
\left(\mathrm{g} \cdot \mathrm{m}^{-2}\right)\end{array}$ & $\begin{array}{c}\text { SLA } \\
\left(\mathrm{cm}^{2} \cdot \mathrm{g}^{-1}\right)\end{array}$ & $\begin{array}{c}\text { CER } \\
\left(\mu \mathrm{mol} \cdot \mathrm{m}^{-2} \cdot \mathrm{s}^{-1}\right)\end{array}$ & $\begin{array}{c}\text { WUE } \\
\left(\mu \mathrm{mol} \cdot \mathrm{mmol}^{-1}\right)\end{array}$ \\
\hline \multirow[t]{4}{*}{ Sun } & Empire & High & 4.4 & 5.5 & 0.8 & 451 & 216 & 15.3 & 4.9 \\
\hline & & Low & 3.2 & 3.4 & 1.0 & 353 & 193 & 10.6 & 4.0 \\
\hline & $5433-22$ & High & 4.5 & 6.6 & 0.7 & 473 & 235 & 15.2 & 4.8 \\
\hline & & Low & 3.6 & 4.3 & 0.9 & 479 & 172 & 11.9 & 4.0 \\
\hline \multirow[t]{4}{*}{ Shade } & Empire & High & 4.2 & 5.1 & 0.9 & 339 & 234 & 13.4 & 4.9 \\
\hline & & Low & 3.5 & 3.4 & 1.1 & 360 & 215 & 10.8 & 4.1 \\
\hline & $5433-22$ & High & 4.5 & 5.5 & 0.9 & 355 & 234 & 13.6 & 4.9 \\
\hline & & Low & 3.7 & 3.4 & 1.2 & 344 & 202 & 12.6 & 4.8 \\
\hline \multicolumn{10}{|c|}{ Significance } \\
\hline \multicolumn{2}{|c|}{ Light (L) } & & NS & NS & $*$ & $* *$ & $* *$ & NS & $*$ \\
\hline \multicolumn{2}{|c|}{ Genotype (G) } & & $* * *$ & NS & NS & NS & NS & NS & NS \\
\hline \multicolumn{2}{|c|}{ Nitrogen $(\mathrm{N})$} & & $* * *$ & $* * *$ & $* *$ & NS & $* * *$ & $* * *$ & $* * *$ \\
\hline \multicolumn{2}{|c|}{$\mathrm{N} \times \mathrm{G}$} & & NS & NS & NS & NS & $*$ & NS & $*$ \\
\hline \multicolumn{2}{|c|}{$\mathrm{N} \times \mathrm{L}$} & & NS & NS & NS & NS & NS & $*$ & NS \\
\hline \multicolumn{2}{|c|}{$\mathrm{G} \times \mathrm{L}$} & & NS & NS & NS & NS & NS & NS & NS \\
\hline \multicolumn{2}{|c|}{$\mathrm{N} \times \mathrm{G} \times \mathrm{L}$} & & NS & NS & NS & NS & NS & NS & NS \\
\hline
\end{tabular}

${ }^{\mathrm{z}}$ Data are presented by full sunlight and shade light environments, by the prostrate (Empire) and upright (TAES 5433-22) zoysiagrass genotypes, and by high $\left(2.5 \mathrm{~g} \cdot \mathrm{m}^{-2}\right)$ and low $\left(0.0 \mathrm{~g} \cdot \mathrm{m}^{-2}\right)$ nitrogen fertilization rates.

***, **, *, and NS $=P<0.001, P<0.01, P<0.05$, and $P>0.05$, respectively. 
Table 2. Trial 2 treatment means and analysis of variance results for daily average evapotranspiration $\left(\mathrm{ET}_{\mathrm{AVE}}\right)$, daily average $\mathrm{ET}_{\text {per }}$ unit leaf area $\left(\mathrm{ET}_{\mathrm{LA}}\right)$, total aboveground dry weight (DW), leaf area index (LAI), specific leaf area (SLA), light-saturated canopy carbon exchange rate (CER), and water use efficiency (WUE). ${ }^{z}$

\begin{tabular}{|c|c|c|c|c|c|c|c|c|c|}
\hline Light & Genotype & Nitrogen & $\begin{array}{c}\mathrm{ET}_{\mathrm{AVE}} \\
\left(\mathrm{mm} \cdot \mathrm{d}^{-1}\right)\end{array}$ & $\begin{array}{c}\mathrm{LAI} \\
\left(\mathrm{m}^{2} \cdot \mathrm{m}^{-2}\right)\end{array}$ & $\begin{array}{c}\mathrm{ET}_{\mathrm{LA}} \\
\left(\mathrm{mm} \cdot \mathrm{d}^{-1} \cdot \mathrm{m}^{-2}\right)\end{array}$ & $\begin{array}{c}\mathrm{DW} \\
\left(\mathrm{g} \cdot \mathrm{m}^{-2}\right)\end{array}$ & $\begin{array}{c}\text { SLA } \\
\left(\mathrm{cm}^{2} \cdot \mathrm{g}^{-1}\right)\end{array}$ & $\begin{array}{c}\text { CER } \\
\left(\mu \mathrm{mol} \cdot \mathrm{m}^{-2} \cdot \mathrm{s}^{-1}\right)\end{array}$ & $\begin{array}{c}\text { WUE } \\
\left(\mu \mathrm{mol} \cdot \mathrm{mmol}^{-1}\right)\end{array}$ \\
\hline \multirow[t]{4}{*}{ Sun } & \multirow[t]{2}{*}{ Empire } & High & 6.4 & 5.1 & 1.2 & 470 & 193 & 16.6 & 2.9 \\
\hline & & Low & 5.6 & 3.6 & 1.6 & 380 & 174 & 9.61 & 1.8 \\
\hline & \multirow[t]{2}{*}{$5433-22$} & High & 6.4 & 5.1 & 1.3 & 504 & 169 & 14.7 & 3.2 \\
\hline & & Low & 5.6 & 3.1 & 1.8 & 354 & 166 & 11.3 & 2.2 \\
\hline \multirow[t]{4}{*}{ Shade } & \multirow[t]{2}{*}{ Empire } & High & 5.6 & 6.8 & 0.9 & 480 & 229 & 15.0 & 4.1 \\
\hline & & Low & 4.4 & 3.3 & 1.4 & 300 & 187 & 10.5 & 2.9 \\
\hline & \multirow[t]{2}{*}{$5433-22$} & High & 5.2 & 6.2 & 0.8 & 491 & 202 & 12.0 & 2.9 \\
\hline & & Low & 4.5 & 5.0 & 1.0 & 460 & 209 & 9.55 & 2.5 \\
\hline \multicolumn{10}{|c|}{ Significance } \\
\hline \multicolumn{2}{|c|}{ Light (L) } & & $* * *$ & $* *$ & $* * *$ & NS & $* * *$ & NS & $* *$ \\
\hline \multicolumn{2}{|c|}{ Genotype (G) } & & NS & NS & NS & NS & NS & NS & NS \\
\hline \multicolumn{2}{|c|}{ Nitrogen $(\mathrm{N})$} & & $* * *$ & $* * *$ & $* * *$ & $* * *$ & $* *$ & $* * *$ & $* * *$ \\
\hline \multicolumn{2}{|c|}{$\mathrm{N} \times \mathrm{G}$} & & NS & NS & NS & NS & $* *$ & NS & NS \\
\hline \multicolumn{2}{|c|}{$\mathrm{N} \times \mathrm{L}$} & & NS & NS & NS & NS & NS & NS & NS \\
\hline \multicolumn{2}{|c|}{$\mathrm{G} \times \mathrm{L}$} & & NS & NS & $*$ & NS & NS & NS & $* *$ \\
\hline \multicolumn{2}{|c|}{$\mathrm{N} \times \mathrm{G} \times \mathrm{L}$} & & NS & $*$ & $*$ & NS & NS & NS & NS \\
\hline
\end{tabular}

${ }^{\mathrm{z}}$ Data are presented by full sunlight and shade light environments, by the prostrate (Empire) and upright (TAES 5433-22) zoysiagrass genotypes, and by high $\left(2.5 \mathrm{~g} \cdot \mathrm{m}^{-2}\right)$ and low $\left(0.0 \mathrm{~g} \cdot \mathrm{m}^{-2}\right)$ nitrogen fertilization rates.

***, **, *, and NS $=P<0.001, P<0.01, P<0.05$, and $P>0.05$, respectively.

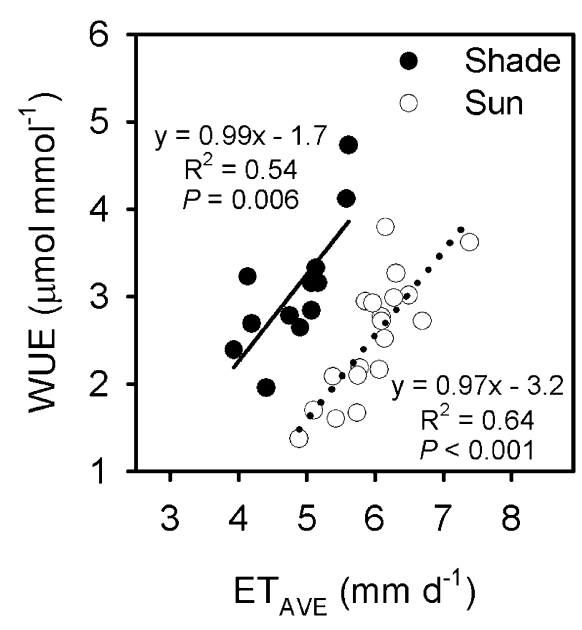

Fig. 3. Relationship between instantaneous water use efficiency (WUE) determined using LI$6400 \mathrm{XT}$ and average daily water use $\left(\mathrm{ET}_{\mathrm{AVE}}\right)$ determined gravimetrically across nitrogen and genotype treatments for sun (o) and shade (•) plants during Trial 2.

was less in Trial 2 than Trial 1, which could have minimized genotype differences, because they were less in Trial 1 at similar (high) LAI values, like under $\mathrm{N}$ fertilization (Fig. 2). Nevertheless, the prostrate genotype never contributed to increased average daily water use in our study. In addition, water use measurements were conducted under non-limiting water conditions in the present study and genotype differences could be greater under water limited conditions (White et al., 1993).

Although effects of genotype could contribute to reduced water use, the effects of $\mathrm{N}$ fertilization on water use were relatively large and consistent across genotype, light environment, and trial. Although there are much data on fate of $\mathrm{N}$ applied to turf, especially with regard to plant $\mathrm{N}$ uptake and $\mathrm{N}$ leaching (Erickson et al., 2008; Petrovic, 1990), there is comparatively little information on the effect of $\mathrm{N}$ on ET. Ebdon et al. (1999) reported increased ET with increased $\mathrm{N}$ fertilization, although the response interacted with phosphorus and potassium fertilization. Barton et al. (2009) showed that not fertilizing Kikuyu grass (Pennisetum clandestinum Hochst. ex Chiov.) could decrease water use by as much as $20 \%$ without loss of quality in an older stand. McGroary et al. (2011) showed that high $\mathrm{N}$ fertilization rates were associated with greater water use by St. Augustinegrass [Stenotaphrum secundatum (Walt.) Kuntze] and bahiagrass (Paspalum notatum Flügge) in field lysimeters. In the present study, N fertilization increased water use by $\approx 20 \%$ compared with non-fertilized zoysiagrass. Thus, there is a growing body of literature that indicates that keeping $\mathrm{N}$ fertilization low could contribute to lower water use by turfgrass ecosystems, but implications for quality need further study (Barton et al., 2009).

Increased water use with $\mathrm{N}$ fertilization was associated with increased LAI (Barton et al., 2009) and increased SLA. In fact, LAI increased more than $\mathrm{ET}_{\mathrm{AVE}}$, which resulted in lower water use per unit leaf area with $\mathrm{N}$ fertilization. In addition, increased $\mathrm{N}$ fertilization also increased turfgrass WUE. Consequently, we believe this study is the first to identify a strong relationship between $\mathrm{ET}_{\mathrm{AVE}}$ and WUE (Fig. 3), which shows a tradeoff between lower water use and WUE with N fertilization in turfgrass. In contrast to studies in which high WUE is inversely related to CER (e.g., Condon et al., 2004), the results in the present study indicate that the effect of $\mathrm{N}$ fertilization on CER (increase of $43 \%$ in Trial 2) was relatively greater than $\mathrm{N}$ fertilization effects on $\mathrm{ET}_{\mathrm{AVE}}$ (increase of $17 \%$ in Trial 2), resulting in high WUE with $\mathrm{N}$ fertilization. Furthermore, these results indicate that efforts to achieve reductions in water use through low $\mathrm{N}$ fertilization can be accomplished but likely at the expense of using water less efficiently to assimilate carbon for plant growth processes. Consequently, we can expect less growth with efforts to reduce water use, which may have a negative effect on crops if it results in reduced yield (Blum, 2009), but in turfgrass, reductions in growth and WUE might be acceptable to minimize water use. However, in high traffic turf areas where vigorous growth is desirable, reducing $\mathrm{ET}_{\mathrm{AVE}}$ through $\mathrm{N}$ management may not be feasible as a result of poor quality and vigor (Barton et al., 2009). We also observed enough variation in the relationship to suggest that genotype or perhaps other management practices that contribute to reduced $\mathrm{ET}_{\mathrm{AVE}}$ but that do not reduce WUE could be possible such as the difference in WUE at the same $\mathrm{ET}_{\mathrm{AVE}}$ that we saw between shade and sun plants in the study (Fig. 3). This relationship between WUE and $\mathrm{ET}_{\mathrm{AVE}}$ also raises questions about limiting fertilization to the dry season in an effort to minimize $\mathrm{N}$ leaching during the wet season in subtropical regions.

In conclusion, the results from this study indicate that a prostrate-growing genotype and especially reduced $\mathrm{N}$ fertilization could contribute to reduced water use by turfgrass in sun and shade. However, there was a tradeoff in WUE associated with no $\mathrm{N}$ fertilization in our study because these zoysiagrasses used water less efficiently for net carbon uptake. Consequently, development of relatively low water use turfgrass genotypes and management practices would ideally maintain or increase WUE to maintain turfgrass growth and vigor. Based on the results of this study, equal or greater water conservation may result from defining and identifying acceptable turfgrass quality parameters for given turf uses and developing management practices and germplasm to meet these criteria. Thus, further research is needed to identify these criteria as well as evaluation of these relationships across a greater number of genotypes and under water deficit conditions.

\section{Literature Cited}

Barton, L., G.G.Y. Wan, R.P. Buck, and T.D. Colmer. 2009. Nitrogen increases evapotranspiration and 
growth of a warm-season turfgrass. Agron. J. 101: 17-24.

Biran, I., B. Bravdo, I. Bushkin-Harav, and E. Rawitz. 1981. Water consumption and growth rate of 11 turfgrasses as affected by mowing height, irrigation frequency, and soil moisture. Agron. J. 73:85-90.

Blum, A. 2009. Effective use of water (EUW) and not water-use efficiency (WUE) is the target of crop yield improvement under drought stress. Field Crops Res. 112:119-123.

Bunce, J.A. 2010. Leaf transpiration efficiency of some drought-resistant maize lines. Crop Sci. 50:1409-1413.

Brueck, H. 2008. Effects of nitrogen supply on water-use efficiency of higher plants. J. Plant Nutr. Soil Sci. 171:210-219.

Carpenter, S.R., N.F. Caraco, D.L. Correll, R.W. Howarth, A.N. Sharpley, and V.H. Smith. 1998. Nonpoint pollution of surface waters with phosphorus and nitrogen. Ecol. Appl. 8:559-568.

Carrow, R.N. 1995. Drought resistance aspects of turfgrasses in the southeast: ET and crop coefficients. Crop Sci. 35:1685-1690.

Condon, A.G., R.D. Richards, G.J. Rebetzke, and G.D. Farquhar. 2004. Breeding for high wateruse efficiency. J. Expt. Bot. 55:2447-2460.

Ebdon, J.S. and A.M. Petrovic. 1998. Morphological and growth characteristics of low- and high-water use kentucky bluegrass cultivars. Crop Sci. 38:143-152.

Ebdon, J.S., A.M. Petrovic, and R.A. White. 1999. Interaction of nitrogen, phosphorus, and potassium on evapotranspiration rate and growth of kentucky blugrass. Crop Sci. 39:209-218.

Erickson, J.E., J.L. Cisar, G.H. Snyder, D.M. Park, and K.E. Williams. 2008. Does a mixed-species landscape reduce inorganic-N leaching following establishment compared to a conventional St. Augustinegrass lawn. Crop Sci. 48:15861594.

Feldhake, C.M., R.E. Danielson, and J.D. Butler. 1983. Turfgrass evapotranspiration. I. Factors influencing rate in urban environments. Agron. J. 75:824-830.

Fry, J.D. and J.D. Butler. 1989. Responses of tall and hard fescue to deficit irrigation. Crop Sci. 29:1536-1541.

Green, R.L., S.I. Sifers, C.E. Atkins, and J.B. Beard. 1991. Evapotranspiration rates of eleven zoysiagrass genotypes. HortScience 26:264266.

Haley, M.B., M.D. Dukes, and G.L. Miller. 2007. Residential irrigation water use in Central Florida. J. Irrig. Drain. Eng. 133:427-434.

Heitholt, J.J. 1989. Water use efficiency and dry matter distribution in nitrogen- and waterstressed winter wheat. Agron. J. 81:464-469.

Kim, K.S. and J.B. Beard. 1988. Comparative turfgrass evapotranspiration rates and associated plant morphological characteristics. Crop Sci. 28:328-331.

LI-COR. 2009. Interfacing custom chambers to the LI-6400 sensor head. 5 Jan. 2010. <http://www. licor.com/env/PDF/AppNote3.pdf>. LI-COR, Inc., Lincoln, NE.
Littell, R.C., G.A. Miliken, W.W. Stroup, R.D. Wolfinger, and O. Schabenberger. 2006. SAS ${ }^{\odot}$ for mixed models. 2nd Ed. SAS Inst., Cary, NC.

McGroary, P.C., J.L. Cisar, J.E. Erickson, G.H. Snyder, J.B. Sartain, and S.H. Daroub. 2011. Water use of St. Augustinegrass and bahiagrass under varying nitrogen rates. Agron. J. 103: 100-106.

Morton, T.G., A.J. Gold, and W.M. Sullivan. 1988. Influence of overwatering and fertilization on nitrogen losses from home lawns. J. Environ. Qual. 17:124-130.

Petrovic, A.M. 1990. The fate of nitrogenous fertilizers applied to turfgrass. J. Environ. Qual. 19:1-14.

Qian, Y.L. and M.C. Engelke. 1999. Performance of five turfgrasses under linear gradient irrigation. HortScience 34:893-896.

Saha, K.S., L.E. Trenholm, and J.B. Unruh. 2005. Effect of fertilizer source on water use of St. Augustinegrass and ornamental plants. HortScience 40:2164-2166.

Shearman, R.C. 1989. Perennial ryegrass cultivar evapotranspiration rates. HortScience 24:767769.

Stanhill, G. 1986. Water use efficiency. Adv. Agron. 39:53-85.

White, R.H., M.C. Engelke, S.J. Morton, and B.A. Ruemmele. 1993. Irrigation water requirement of zoysiagrass, p. 587-593. In: Carrow, R.N., et al. (ed.). Internation Turfgrass Soc. Research J. Intertec Publishing Corp., Overland Park, KS. 